\title{
Peluang Kejadian Ototoksisitas pada Penggunaan Kanamisin dalam Pengobatan Tuberkulosis Resisten Obat Ganda Selama Satu Bulan
}

\author{
Lussie Rakhmawati, ${ }^{1}$ Ratna Anggraeni Agustian, ${ }^{2}$ Wijana $^{2}$ \\ ${ }^{1}$ Rumah Sakit Siloam Sriwijaya Palembang, ${ }^{2}$ Departemen Ilmu Kesehatan Telinga Hidung Tenggorok-Bedah \\ Kepala Leher Fakultas Kedokteran Universitas Padjadjaran/Rumah Sakit Dr. Hasan Sadikin Bandung
}

\begin{abstract}
Abstrak
Obat ototoksik adalah obat yang berpotensi menimbulkan reaksi toksik pada struktur di koklea, vestibulum, kanalis semisirkularis, dan otolith. Kanamisin merupakan obat yang digunakan dalam pengobatan tuberkulosis resisten obat ganda (multidrug resistant/TB MDR) dan berpotensi ototoksik. Penelitian ini bertujuan mengetahui peluang terjadinya ototoksisitas sebagai langkah awal deteksi dini pada penggunaan kanamisin dalam pengobatan TB MDR. Penelitian ini berupa studi deskriptif yang dilakukan secara prospektif di RS Dr. Hasan Sadikin Bandung periode Januari-Juni 2014 dengan subjek adalah penderita TB MDR. Pemeriksaan awal, yaitu audiometri nada murni, timpanometri dan DPOAE dilakukan sebelum terapi, kemudian dilakukan pemeriksaan lanjutan dengan DPOAE setiap 3 hari selama 1 bulan pertama pengobatan. Hasil penelitian menunjukkan gangguan koklea pada telinga kanan dan kiri mulai frekuensi $10.000 \mathrm{~Hz}$ pada hari ke-19-21, kemudian mengenai frekuensi $8.000 \mathrm{~Hz}$ pada hari ke-25-27. Terdapat hubungan negatif gangguan koklea akibat kanamisin dengan usia, namun tidak terdapat hubungan negatif gangguan koklea dengan jenis kelamin dan indeks masa tubuh. Simpulan, peluang kejadian ototoksik pada penderita TB MDR yang mendapat terapi kanamisin terjadi mulai pada akhir minggu kedua serta mengenai frekuensi tinggi terlebih dahulu serta berlanjut ke frekuensi yang lebih rendah. [MKB. 2015;47(4):224-30]
\end{abstract}

Kata kunci: Deteksi dini, kanamisin, ototoksik, TB MDR

\section{Probability of Kanamycin Ototoxicity in Multidrug Resistant Tuberculosis Patient during First Month Treatment}

\begin{abstract}
Ototoxic drugs are medicines that cause toxic reactions to structures in the cochlea, vestibule, semicircular canal, and otolith. Kanamycin is a drug used in the treatment of Multidrug Resistant Tuberculosis (MDR TB) and potentially ototoxic. This study aimed to determine the possibility of kanamycin ototoxicity as an initial step of early detection in MDR TB treatment. This study was a descriptive study conducted prospectively and performed in dr. Hasan Sadikin General Hospital Bandung during the period of January-June 2014. The study involved MDR TB patients. Preliminary examinations were performed using pure tone audiometry, tympanometry and DPOAE, which was then followed by further investigations using DPOAE examination every 3 days during the first month of treatment. The results showed cochlear disorders on the right and left ear started to $10,000 \mathrm{~Hz}$ frequency on days 19-21, then the frequency of 8,000 Hz on days 25-27. There was a negative relationship between cochlear disorders due to use of kanamycin with age, and no correlation between cochlear disorders with gender and body mass index. In conclusion, possibility of kanamycin ototoxicity in patients with MDR TB begins at the end of the second week, first on high frequency and continues to lower frequency. [MKB. 2015;47(4):224-30]
\end{abstract}

Key words: Early detection, MDR TB, kanamycin, ototoxic

Korespondensi: Lussie Rakhmawati, dr., SpTHT-KL, Rumah Sakit Siloam Sriwijaya Palembang, Jalan POM IX, Ilir Barat I, Sumatera Selatan 30137, mobile 081223939858, e-mail hanin1vareta@gmail.com 


\section{Pendahuluan}

Obat ototoksik didefinisikan sebagai obat yang memiliki potensi menimbulkan reaksi toksik pada struktur di telinga dalam seperti koklea, vestibulum, kanalis semisirkularis dan otolit. Kerusakan pada struktur ini dapat memberikan gejala berupa gangguan pendengaran, tinitus, dan juga gangguan keseimbangan. ${ }^{1}$ Kerusakan pada telinga dalam yang disebabkan oleh obat ototoksik seringkali ditemukan di dalam praktik kedokteran sehari-hari. Di beberapa negara yang berkembang, obat seperti aminoglikosida sering dipergunakan untuk pengobatan pneumonia, diare, dan tuberkulosis (TB) paru serta diperoleh ototoksisitas yang tinggi. ${ }^{2}$

Pengenalan aminoglikosida pertama adalah streptomisin pada tahun 1944 oleh Waxman, menandai era/masa baru terapi antibiotik untuk pengobatan tuberkulosis. Hinshaw dan Feldman di Mayo Clinic menemukan toksisitas vestibuler pada sebagian besar pasien akibat penggunaan obat ini. Beberapa tahun kemudian, penggunaan analog streptomisin, yaitu dihydrostreptomycin mempunyai insidensi toksisitas koklea yang sangat tinggi sehingga ditarik dari peredaran. Aminoglikosida lain seperti neomisin, kanamisin, netilmisin, tobramisin, dan amikasin mempunyai tingkat toksisitas koklea yang sangat tinggi bila digunakan secara sistemik. Era berikutnya, penggunaan gentamisin menyebabkan cedera vestibular sebanyak $3 \%{ }^{2}$

Tuberkulosis merupakan salah satu penyebab kematian dengan prevalensi yang cukup tinggi. World Health Organization (WHO) pada tahun 2011 prevalensi tuberkulosis adalah sebesar 8,7 juta kasus dan TB MDR sebanyak 0,5 juta kasus dengan kasus baru 60.000 kasus. Prevalensi TB di Indonesia tahun 2011 adalah 281/100.000 penduduk dengan angka kematian 27/100.000 penduduk. Kasus baru TB MDR sebanyak 1,9\% dan TB MDR yang berasal pada kasus TB yang telah diobati didapatkan $12 \%{ }^{3}$

Tuberkulosisresisten obatgandadidefinisikan sebagai tuberkulosis yang resisten terhadap isoniazid dan rifampisin, dengan atau tanpa resisten terhadap obat anti-TB lain. Sisa obat oral lini pertama harus tepat dikombinasikan dengan tambahan obat lini kedua yang terdiri atas fluorokuinolon (siprofloksasin, ofloksasin, aminoglikosida injeksi (amikasin, kanamisin, kapreomisin), levofloksasin, moksifloksasin, gatifloksasin), anti-TB bakteriostatik lini kedua (etionamid, protionamid, sikloserin, dan asam salisilat paraamino, thiocetazone) serta antituberkulosis lainnya (klofazimin, amoksisilin/ clavuanate, klaritromisin, linezolid). ${ }^{4}$

Data pada poliklinik TB MDR Ilmu Penyakit Dalam Rumah Sakit Dr. Hasan Sadikin Bandung selama satu tahun sejak Januari 2013-Desember 2013 didapatkan 127 penderita TB MDR yang memperoleh pengobatan obat antituberkulosis (OAT) lini kedua dengan injeksi aminoglikosida, yaitu kanamisin dan juga dilaporkan 15 (11,8\%) pasien dengan gangguan pendengaran setelah 3-6 bulan pemberian terapi.

Pengobatan TB MDR lebih kompleks terdiri atas 2 (dua) tahap, yaitu tahap awal dan tahap lanjutan, serta mempergunakan OAT yang efek sampingnya lebih banyak. Pengobatan TB MDR memerlukan waktu yang lebih lama daripada pengobatan pasien TB bukan MDR, yaitu sekitar 19-24 bulan. Pada tahap awal pasien akan mendapat OAT lini kedua minimal 4 jenis OAT yang masih sensitif, salah satunya adalah OAT injeksi, yaitu kanamisin. Pada tahap lanjutan semua OAT lini kedua yang dipakai pada tahap awal dilanjutkan kecuali OAT injeksi. ${ }^{5}$

Ototoksisitas dan juga nefrotoksisitas diakui sebagai efek samping aminoglikosida. Efek samping nefrotoksisitas yang biasanya bersifat reversibel, sedangkan pada ototoksisitas bersifat permanen karena disebabkan oleh kematian sel-sel rambut luar pada organ Corti dan sel sensorik tipe I pada organ vestibular. Waktu paruh kanamisin di perilimfe adalah 15 jam, 10 kali waktu paruhnya dalam darah. Peningkatan konsentrasi kanamisin di perilimfe dihubungkan dengan dosis harian berulang. ${ }^{6,7}$

Kanamisin mempunyai efek samping utama pada koklea, dapat menghasilkan karakteristik gangguan dengar sensorineural, jarang terjadi cedera pada vestibular. Gangguan dengar oleh karena pemberian kanamisin dapat terjadi setelah 3-4 hari pemberian ataupun tertunda dalam hitungan hari, minggu, ataupun bulan sesudah dilakukan terapi. Paparan awal obat ototoksik biasanya dapat memengaruhi daerah basal koklea. Paparan lanjutan menyebabkan terjadi penyebaran kerusakan ke arah apeks. ${ }^{2,8,9}$ Meskipun penggunaan dari aminoglikosida tidak dapat dihentikan pada individu dengan TB MDR, terdapat strategi yang dapat dilakukan untuk dapat mengurangi gangguan dengar pada pasien tersebut, yaitu dengan melakukan monitoring audiologi. ${ }^{5}$

Monitoring audiologi pada suatu ototoksisitas mempunyai dua tujuan utama, yaitu deteksi dini gangguan dengar serta intervensi audiologi apabila sudah timbul gangguan pendengaran. ${ }^{10}$ Deteksi dini pada gangguan pendengaran akibat obat ototoksik memberikan kesempatan para 
dokter untuk mengevaluasi pemberian terapi dalam meminimalkan atau mencegah gangguan pendengaran yang membutuhkan rehabilitasi. ${ }^{5}$

Beberapa penelitian yang mengenai efek samping pengobatan TB MDR sudah ditelaah sebelumnya. Duggal dan Sarkar ${ }^{6}$ melaporkan $15,4 \%$ penderita TB MDR yang mengalami gangguan pendengaran frekuensi tinggi setelah 2 bulan pemberian injeksi kanamisin. Rafique dkk. ${ }^{11}$ melaporkan bahwa 15 dari 38 penderita TB MDR yang mengalami gangguan pendengaran setelah 1 bulan menerima injeksi streptomisin. Reviono dkk. ${ }^{12}$ melaporkan $15,4 \%$ pasien TB MDR yang mengalami penurunan pendengaran diukur dengan audiometri nada murni pada bulan pertama terapi kanamisin dan tidak ada hubungan antara penurunan pendengaran dan riwayat pengobatan streptomisin.

Tujuan penelitian ini mengevaluasi secara dini peluang terjadi ototoksisitas pada penggunaan kanamisin dalam pengobatan TB MDR sebagai langkah awal deteksi dini ototoksisitas.

\section{Metode}

Penelitian ini merupakan studi deskriptif yang dilakukan secara prospektif dengan subjek penelitian adalah penderita TB MDR baru yang akan mendapat pengobatan injeksi kanamisin. Parameter yang diukur adalah pemeriksaan distortion product otoacustic emission (DPOAE) yang dilakukan setiap 3 hari selama 1 bulan pertama pengobatan.

Pasien yang menjadi subjek dalam penelitian sejumlah 38 orang. Kejadian ototoksik dianalisis pada kedua telinga dilakukan secara terpisah sehingga didapatkan sebanyak 76 data telinga dari 38 pasien.

\section{Hasil}

Karakteristik umum penderita TB MDR yang menjadi subjek penelitian meliputi usia, jenis kelamin, indeks massa tubuh, dan timpanometri. Audiometri nada murni dan DPOAE sebelum terapi pada semua subjek memiliki nilai normal sesuai kriteria inklusi.

Pada penelitian ini didapatkan bahwa lakilaki lebih banyak dibanding dengan perempuan dan kelompok usia terbanyak adalah kelompok usia 20-29 tahun dan 40-49 tahun. Indeks massa tubuh (IMT) didapatkan pasien dengan berat badan normal lebih banyak daripada berat badan kurang. Pemeriksaan timpanometri
Tabel 1 Karakteristik Subjek Penelitian

\begin{tabular}{lc}
\hline Karakteristik & $\begin{array}{c}\text { Jumlah Subjek } \\
\text { (Persentase) }\end{array}$ \\
\hline Jenis kelamin & 22 \\
Laki-laki & 16 \\
Perempuan & \\
Usia (tahun) & 4 \\
$<20$ & 10 \\
$20-29$ & 8 \\
$30-39$ & 10 \\
$40-49$ & 6 \\
$\geq 50$ & 15 \\
Indeks massa tubuh & 23 \\
Kurang & 0 \\
Normal & \\
Lebih & 33 \\
Timpanometri & 5 \\
Tipe A & \\
Tipe As & \\
\hline
\end{tabular}

didapatkan mayoritas tipe A.

Selama penelitian ini dilakukan pemeriksaan DPOAE dengan protokol ototoksik mulai dari frekuensi $1.500 \mathrm{~Hz}$ sampai dengan $10.000 \mathrm{~Hz}$ diperoleh gangguan koklea yang ditandai dengan hasil refer pada frekuensi $8000 \mathrm{~Hz}$ dan 10.000 $\mathrm{Hz}$, sedangkan pada frekuensi kurang dari 8.000 $\mathrm{Hz}$ tidak didapatkan gangguan yang ditandai dengan hasil pass.

Pada Gambar 1 tampak hasil pemeriksaan DPOAE pada frekuensi $10.000 \mathrm{~Hz}$ telinga kanan dan kiri didapatkan mulai terdapat gangguan pada hari ke-19-21.

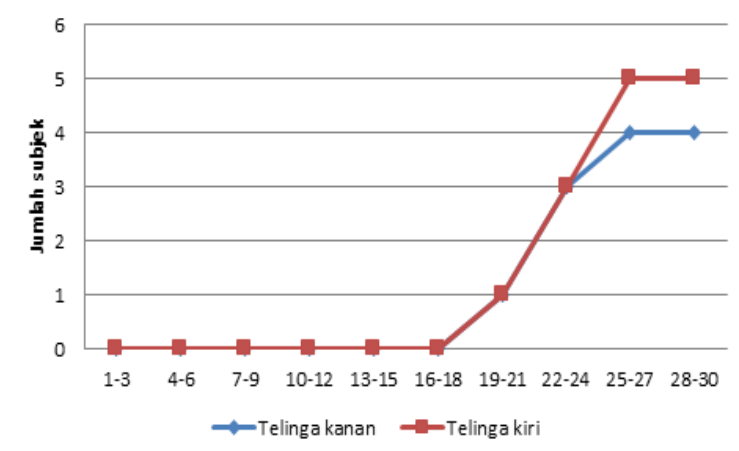

Gambar 1 Peluang Kejadian Ototoksisitas $10.000 \mathrm{~Hz}$ Telinga Kanan dan Kiri 
Tabel 2 Hasil Pemeriksaan DPOAE pada Frekuensi 10.000 Hz berdasarkan Jenis Kelamin, Usia, dan IMT

\begin{tabular}{|c|c|c|c|c|c|c|}
\hline & \multicolumn{2}{|c|}{ Telinga Kanan } & \multirow{2}{*}{$\mathbf{p}$} & \multicolumn{2}{|c|}{ Telinga Kiri } & \multirow{2}{*}{$\mathbf{p}$} \\
\hline & Pass & Refer & & Pass & Refer & \\
\hline \multicolumn{7}{|l|}{ Jenis kelamin } \\
\hline Laki-laki & 19 & 3 & $\left.0,624^{*}\right)$ & 18 & 4 & $\left.0,374^{*}\right)$ \\
\hline Perempuan & 15 & 1 & & 15 & 1 & \\
\hline \multicolumn{7}{|l|}{ Usia (tahun) } \\
\hline$<20$ & 4 & 0 & $\left.0,144^{* *}\right)$ & 4 & 0 & $\left.0,348^{* *}\right)$ \\
\hline $20-29$ & 10 & 0 & & 9 & 1 & \\
\hline $30-39$ & 8 & 0 & & 8 & 0 & \\
\hline $40-49$ & 8 & 2 & & 8 & 2 & \\
\hline$\geq 50$ & 4 & 2 & & 4 & 2 & \\
\hline \multicolumn{7}{|l|}{ IMT } \\
\hline Kurang & 14 & 1 & $\left.0,516^{*}\right)$ & 14 & 1 & $\left.0,516^{*}\right)$ \\
\hline Normal & 20 & 3 & & 19 & 4 & \\
\hline
\end{tabular}

Keterangan: *) dihitung berdasarkan uji chi square; ${ }^{* *}$ ) dihitung berdasarkan uji exact Fisher

Gambar 2 memperlihatkan hasil pemeriksaan DPOAE pada frekuensi $8.000-10.000 \mathrm{~Hz}$ telinga kanan terdapat gangguan mulai pada hari ke25-27.

Tabel 2 memperlihatkan hasil pemeriksaan DPOAE pada frekuensi $10.000 \mathrm{~Hz}$ berdasarkan atas jenis kelamin, usia, serta IMT. Didapatkan jumlah subjek dengan gangguan koklea pada telinga kanan maupun kiri berdasarkan jenis kelamin mempunyai nilai p sebesar 0,624 dan 0,374, menjelaskan tidak terdapat perbedaan yang bermakna. Berdasarkan usia mempunyai nilai $\mathrm{p}=0,144$ dan $\mathrm{p}=0,348$. Hal ini menjelaskan bahwa tidak terdapat perbedaan yang bermakna. Indeks massa tubuh mempunyai nilai p sebesar 0,516 . Hal ini menjelaskan bahwa tidak terdapat perbedaan yang bermakna.

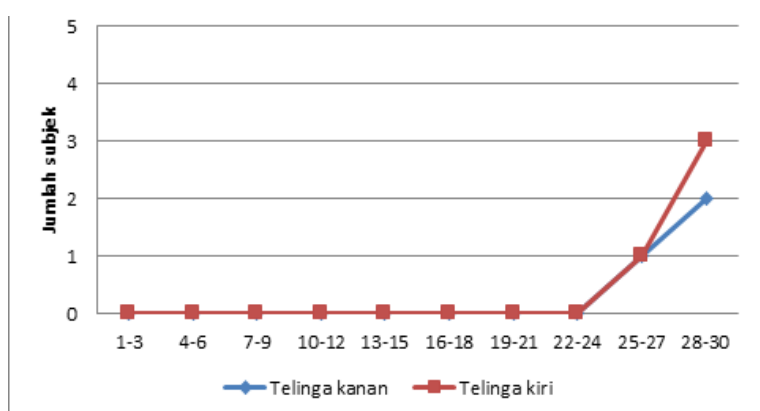

Gambar 2 Peluang Kejadian Ototoksisitas 8.000$10000 \mathrm{~Hz}$ Telinga Kanan dan Kiri
Tabel 3 memperlihatkan hasil pemeriksaan DPOAE frekuensi 8.000-10.000 Hz berdasarkan jenis kelamin, usia dan juga IMT. Pada tabel tersebut didapatkan jumlah subjek dengan gangguan koklea pada telinga kanan maupun kiri dibandingkan berdasarkan jenis kelamin mempunyai nilai $p=0,499$ dan $p=0,249$. Hal ini menjelaskan bahwa tidak terdapat perbedaan yang bermakna. Jumlah subjek dengan gangguan koklea berdasarkan usia memiliki nilai $\mathrm{p}=0,024$ dan $p=0,059$. Keadaan ini menjelaskan bahwa terdapat perbedaan yang bermakna pada telinga kanan dan telinga kiri. Dibanding dengan indeks massa tubuh mempunyai nilai $\mathrm{p}=0,516$. Hal ini menjelaskan bahwa tidak terdapat perbedaan yang bermakna.

\section{Pembahasan}

Pada hasil penelitian diperoleh bahwa penderita TBMDRyangmenjadi subjekpenelitianterbanyak laki-laki dibanding dengan perempuan. Keadaan ini sesuai dengan penelitian yang dilaporkan oleh Rafique dkk. ${ }^{11}$ Hal ini tidak sesuai dengan penelitian yang dilaporkan peneliti-peneliti lain seperti Reviono dan Ramma. ${ }^{21}$ Perbedaan ini disebabkan karena perbedaan jumlah antara laki-laki dan perempuan pada penelitian yang satu dan yang lainnya tidak signifikan.

Berdasarkan usia, bahwa hasil penelitian menunjukkan penderita paling banyak pada usia 
Tabel 3 Hasil pemeriksaan DPOAE Pada Frekuensi 8000-10000 Hz Berdasarkan Jenis Kelamin, Usia dan IMT

\begin{tabular}{|c|c|c|c|c|c|c|}
\hline & \multicolumn{2}{|c|}{ Telinga Kanan } & \multirow{2}{*}{$\mathrm{p}$} & \multicolumn{2}{|c|}{ Telinga Kiri } & \multirow{2}{*}{$\mathrm{p}$} \\
\hline & pass & refer & & pass & refer & \\
\hline \multicolumn{7}{|l|}{ Jenis Kelamin } \\
\hline Laki-laki & 20 & 2 & $\left.0,499^{*}\right)$ & 19 & 3 & $\left.0,249^{*}\right)$ \\
\hline Perempuan & 16 & 0 & & 16 & 0 & \\
\hline \multicolumn{7}{|l|}{ Usia (tahun) } \\
\hline$<20$ & 4 & 0 & $\left.0,024^{* *}\right)$ & 4 & 0 & $\left.0,059^{* *}\right)$ \\
\hline $20-29$ & 10 & 0 & & 9 & 1 & \\
\hline $30-39$ & 8 & 0 & & 8 & 0 & \\
\hline $40-49$ & 10 & 0 & & 10 & 0 & \\
\hline$\geq 50$ & 4 & 2 & & 4 & 2 & \\
\hline \multicolumn{7}{|l|}{ IMT } \\
\hline Kurang & 15 & 0 & $\left.0,516^{*}\right)$ & 15 & 0 & $\left.0,516^{*}\right)$ \\
\hline Normal & 21 & 2 & & 20 & 3 & \\
\hline
\end{tabular}

Keterangan: *) dihitung berdasarkan uji chi square; *) dihitung berdasarkan uji exact Fisher

20-29 tahun dan 40-49 tahun. Hal ini sesuai dengan hasil penelitian Reviono dkk.12 dan beberapa peneliti lain. Sebagian besar subjek penelitian merupakan usia produktif karena aktivitasnya yang lebih tinggi dibanding dengan kelompok usia yang lain sehingga kontak dengan lingkungan juga lebih tinggi. ${ }^{9}$

Hasil penelitian juga memperlihatkan IMT pada penderita TB MDR didapatkan jumlah pasien dengan berat badan normal lebih banyak dibanding dengan berat badan kurang. Hal ini menunjukkan bahwa status gizi penderita TB MDR masih cukup baik sehingga pengobatannya merupakan hal yang sangat penting untuk diperhatikan.

Berdasarkan atas hasil pemeriksaan DPOAE menunjukkan bahwa peluang kejadian ototoksik pada penderita TB MDR yang mendapat terapi kanamisin terjadi mulai pada hari ke-19-21 pada frekuensi $10.000 \mathrm{~Hz}$ dan hari ke-25-27 pada frekuensi $8.000 \mathrm{~Hz}$, serta meningkat dengan semakin bertambahnya waktu.

Gerak gelombang yang dihasilkan oleh bunyi frekuensi tinggi mempunyai pergeseran maksimum pada bagian basal koklea, sedangkan bunyi frekuensi rendah mempunyai pergeseran maksimal lebih ke arah apeks koklea, Faktor yang memberi kontribusi pada cochlear amplifier adalah gerakan sel rambut luar, sifat mekanik stereosilia, dan membran tektorial. ${ }^{13}$

Kanamisin merusak sel-sel rambut luar
(OHC), namun sebagian besar sel pendukung dan sel-sel rambut dalam (IHC) tidak terpengaruh. Hal ini disebabkan oleh peningkatan aktivasi dan translokasi faktor nuklir (NF)kB dalam inti IHC dan sel pendukung yang merupakan peranan sinyal sel ROS-induced. Selain itu, sel rambut luar memiliki kadar antioksidan yang lebih rendah dibanding dengan tipe sel organ korti yang lain sehingga sel rambut luar memiliki kecenderungan kerusakan yang lebih awal. ${ }^{9}$

Gejala toksisitas koklea meliputi gangguan pendengaran dan tinnitus, sedangkan toksisitas vestibular terdiri atas ketidakseimbangan dan pusing. Toksisitas koklea biasanya pertama memengaruhi frekuensi tinggi dan kemudian meluas ke arah frekuensi yang lebih rendah bergantung pada lama paparan dan dosis yang diberikan. ${ }^{14}$

Paparan awal obat ototoksik biasanya dapat memengaruhi daerah basal koklea. Paparan lanjutan menyebabkan penyebaran kerusakan ke arah apeks. Oleh karena itu, toksisitas koklea pada awalnya memengaruhi frekuensi tinggi dan kemudian meluas ke frekuensi yang lebih rendah. Kerusakan pada koklea yang terjadi pada sel rambut luar menyebabkan gangguan pendengaran frekuensi tinggi serta memengaruhi proses emisi otoakustik. .,14,15 $^{8}$

Hasil pemeriksaan DPOAE sesuai dengan penjelasan bahwa ototoksisitas akibat kanamisin menyebabkan kerusakan sel rambut pada basal 
koklea sehingga gangguan pendengaran yang timbul terlebih dahulu pada frekuensi tinggi. Frekuensi ultra tinggi $(>8 \mathrm{kHz}$ ) tidak diperiksa secara rutin sehingga kejadian gangguan pada pendengaran akibat pemberian kanamisin itu sering terabaikan. ${ }^{8}$

Gangguan koklea yang timbul pada penelitian ini didapatkan seorang pasien yang memiliki gangguan unilateral. Keadaan ini dapat terjadi pada ototoksisitas akibat kanamisin oleh karena gangguan pendengaran bilateral mendominasi, namun tidak jarang pula ditemukan unilateral. Kanamisin cenderung menyebabkan gangguan pada pendengaran unilateral dibanding dengan aminoglikosida lainnya. ${ }^{8}$

Berdasarkan pengamatan subjek penelitian selama 1 bulan didapatkan gangguan pada koklea akibat pemberian kanamisin mulai timbul pada hari ke-19-21 atau akhir minggu kedua. Hal ini sesuai dengan panduan monitoring audiologi berdasarkan American Academy of Audiology, yaitu pemeriksaan lanjutan sebagai evaluasi atau monitoring audiologi pada penggunaan aminoglikosida sebaiknya dilakukan seminggu atau 2 (dua) minggu sekali. Monitoring dapat dilanjutkan meskipun penggunaannya sudah dihentikan oleh karena aminoglikosida dapat menganggu pendengaran yang tertunda sampai beberapa bulan setelah pengobatan dihentikan. ${ }^{10}$

Saat ini tidak terdapat terapi untuk dapat menyembuhkan kerusakan akibat obat-obatan ototoksik, akan tetapi peneliti dan juga klinisi mencoba untuk menemukan metode baru untuk meminimalisir cedera ototoksik, salah satunya menggunakan monitoring audiologi. ${ }^{1}$ Monitoring audiologi pada ototoksisitas memiliki dua tujuan utama, yaitu deteksi dini gangguan pendengaran serta intervensi audiologi jika sudah timbul gangguan pendengaran. Dalam hal ini tujuan monitoring audiologi pada penelitian ini adalah mendeteksi dini gangguan pada koklea dilihat pada pemeriksaan DPOAE sehingga mampu dilakukan intervensi secara dini. Apabila tujuan utama monitoring audiologi sudah tercapai maka dapat dilakukan tujuan berikutnya, yaitu penatalaksanaan gangguan dengar yang tidak dapat diobati secara medikamentosa seperti konseling, strategi komunikasi, dan amplifikasi atau alat bantu dengar. ${ }^{10}$

Pada pemeriksaan DPOAE frekuensi 10.000 $\mathrm{Hz}$ penderita TB MDR yang mendapat terapi kanamisin dihubungkan dengan karakteristik, yaitu jenis kelamin, usia, dan indeks massa tubuh diperoleh jumlah subjek dengan gangguan koklea pada telinga kanan maupun kiri dibandingkan berdasarkan jenis kelamin, usia dan IMT tidak terdapat perbedaan yang bermakna.

Pada pemeriksaan DPOAE frekuensi 8.000 $\mathrm{Hz}$ penderita TB MDR yang mendapat terapi kanamisin dihubungkan dengan karakteristik, yaitu jenis kelamin, usia, dan juga indeks massa tubuh diperoleh jumlah subjek dengan gangguan koklea pada telinga kanan maupun telinga kiri dibandingkan berdasarkan jenis kelamin dan IMT tidak terdapat perbedaan yang bermakna. Namun, jumlah subjek penelitian berdasarkan usia terdapat perbedaan yang bermakna pada telinga kanan dan juga perbedaan yang hampir bermakna pada telinga kiri.

Perbandingan hasil pemeriksaan DPOAE dengan karakteristik subjek penelitian, yaitu usia, jenis kelamin, dan indeks massa tubuh (IMT) memperlihatkan tidak terdapat hubungan antara jenis kelamin dan indeks massa tubuh dengan peluang terjadinya ototoksisitas pada penggunaan kanamisin dalam pengobatan $\mathrm{TB}$ MDR, sedangkan usia merupakan faktor yang memengaruhi oleh karena berhubungan dengan proses degenerasi yang memperlihatkan hasil pemeriksaan yang hampir sama, yaitu gangguan pada fungsi koklea. Oleh karena jumlah sel menurun seiring bertambahnya usia dan proses degenerasi, pasien yang lanjut usia lebih rentan terhadap ototoksisitas. ${ }^{16}$

Keterbatasan penelitian ini adalah jumlah sampel yang sangat sedikit. Begitu pula dengan keterbatasan kemampuan pasien untuk datang ke RSHS dikarenakan jarak rumah pasien yang cukup jauh serta keterbatasan alat pemeriksaan pendengaran, khususnya pada high frequency audiometry (HFA).

Simpulan, peluang kejadian ototoksik pada penderita TB MDR yang mendapatkan terapi kanamisin terjadi mulai pada akhir minggu kedua serta mengenai frekuensi tinggi terlebih dahulu $(10.000 \mathrm{~Hz})$ serta berlanjut ke frekuensi yang lebih rendah $(8.000 \mathrm{~Hz})$. Perlu dilakukan suatu monitoring audiologi pada penderita TB MDR yang mendapat terapi kanamisin sesuai dengan hasil penelitian ini sebagai acuan, yaitu monitoring setiap 2 minggu.

\section{Daftar Pustaka}

1. Mudd PA. Inner ear, ototoxicity (diunduh 7 Mei 2012). Tersedia dari: http://emedicine. medscape.com/article/857679-overview.

2. Schuman RM. Ototoxicity. Dalam Bailey BJ, penyunting. Head \& neck surgery otolaryngology. Edisi ke-4. Texas: Lippincott Williams \& Wilkins; 2006. hlm. 2202-5. 
3. World Health Organization. Key point. WHO Report 2012: Global Tuberculosis Control 2012 surveillance, planning, financing. Geneva, Switzerland: WHO; 2012.

4. World Health Organization. Guidelines for management of drug resistant tuberculosis. Geneva, Switzerland: WHO; 2011.

5. Direktorat Jenderal Pengendalian Penyakit dan Penyehatan Lingkungan. Pengendalian TB Resisten Obat. Sub Direktorat Tuberkulosis. Jakarta: DepKes RI; 2011.

6. Duggal P, Sarkar M. Audiologic monitoring of multi-drug resistant tuberculosis patients on aminoglycoside treatment with long term follow-up. BMC Ear, Nose and Throat Disorders. 2007;7:5.

7. Anonim. Ototoxicity (diunduh Agustus 2013). Tersedia dari: www.vestibular.org. 2011.

8. Stringer SP, Meyerhoff WL. Paparella Otolaryngology: totoxicity. Volume II. Edisi ke-3. Pennsylvania: Saunders; 1990.

9. Rybak LP, Whitworth CA. Ototoxicity: therapeutic opportunities. Drug Discov Today. 2005;10(19):1313-21.

10. Durrant JD, Campbell K, Fausti S, Guthrie O, Jacobson G, Lonsbury B, dkk. American
Academy of Audiology Position Statement and Clinical Practice Guidelines: Ototoxicity Monitoring; 2009.

11. Rafique A, Dastgir M, Jamalullah M, Maqbool S, Basher S, Rashid M. Streptomycin associated hearing loss in patients treated for multidrug resistant tuberculosis. Isra Med J. 2012;4(3):139-42.

12. Reviono, Widayanto, Harsini, Aphridasari J, Sutanto YS. Streptomisin dan insidens penurunan pendengaran pada pasien multidrug resistant tuberculosis di Rumah Sakit Dr. Moewardi. Surakarta. J Respir Indo. 2013;33:167-72.

13. Dhingra PL. Diseases of ear, nose and throat. Edisi ke-5. New Delhi: Elsevier; 2010.

14. Huth ME, Ricci AJ, Cheng AG. Mechanisms of aminoglycoside ototoxicity and targets of hair cell protection. Int J Otolaryngol. 2011;19:1-9.

15. Probst R, Grevers G, Iro H. Basic otolaryngology. Germany: Thieme; 2006.

16. Chambers HF Senyawa antimikroba aminoglikosida. Dalam: Joel $\mathrm{H}$, Lee $\mathrm{L}$, penyunting. Dasar farmakologi terapi. Volume 2. Jakarta: EGC; 2007. hlm. 1195204. 